\title{
DETERMINACIÓN DE LAS PÉRDIDAS CAUSADAS POR LA MOSCA BLANCA DE LOS INVERNADEROS (Trialeurodes vaporariorum) EN CULTIVOS DE TOMATE BAJO INVERNADERO
}

\author{
SCOtTA, R. R. ${ }^{1} ;$ SÁnCheZ, D. A. E. ${ }^{1} \&$ ArRegul M. C. ${ }^{1}$
}

\begin{abstract}
RESUMEN
La mosca blanca de los invernaderos produce daños en tomate, al afectar el crecimiento, transmitir virus que provocan enfermedades y favorecer el desarrollo de fumagina. El objetivo de este trabajo fue determinar las pérdidas causadas por Trialeurodes vaporariorum sobre el rendimiento total y comercial de tomate bajo invernadero. El trabajo se realizó en CECIF-FCA-UNL, en cultivos trasplantados el 18/9/2002 y el 5/8/2004 a una densidad de 2,4 plantas. $\mathrm{m}^{-2}$. Los tratamientos fueron: a) cultivo libre de $T$. vaporariorum desde inicio de floración hasta cosecha, b) desde inicio de fructificación hasta cosecha y c) durante todo el ciclo, aplicando imidacloprid a una dosis de $52 \mathrm{~g}$ i.a. $\mathrm{ha}^{-1}$. Antes de cada aplicación se monitorearon adultos y ninfas de T. vaporariorum; a cosecha se determinó el rendimiento total y comercial. El rendimiento total no tuvo diferencias entre tratamientos. El rendimiento comercial fue mayor en el tratado durante todo el ciclo.

Palabras claves: Trialeurodes vaporariorum, fumagina, pérdidas, rendimiento
\end{abstract}

\section{SUMMARY}

Determination of losses caused by the greenhouse whitefly (Trialeurodes vaporariorum) in greenhouse tomatoes.

The greenhouse whitefly damages tomatoes by affecting growth, spreading disease and favouring the growth of sooty mold. We aimed to determine the losses caused by Trialeurodes vaporariorum on the total and commercial yields of greenhouse tomatoes. The study was carried out in crops at CECIF-FCA- UNL, which were transplanted on the 18/9/2002 and 5/8/2004 at a density of 2.4 plants. $\mathrm{m}^{-2}$. The treatments were: a) free culture T. vaporariorum from the start of flowering to harvest $b$ ) from the start of fruiting to harvest and c) throughout the cycle, using imidacloprid at a dose of $52 \mathrm{~g}_{\text {ai.ha }}{ }^{-1}$. Before each application adults and nymphs of $T$. vaporariorum were monitored and at harvest the total and commercial yields were determined. The total yield did not vary much, whereas the greatest commercial yield took place throughout the cycle.

Key words: Trialeurodes vaporariorum, fumagina, losses, yield.

1.- Facultad de Ciencias Agrarias (UNL). Kreder 2805. (3080) Esperanza, provincia de Santa Fe. Email: rrscotta@fca.unl.edu.ar

Manuscrito recibido el 10 de abril de 2014 y aceptado para su publicación el 2 de agosto de 2014. 